\title{
The Effectiveness Of The Auditing Standards To Detect Fraudulent Financial Reporting Activities In Financial Statement Audits In Malaysia
}

Glen D. Moyes, DBA, University of Texas-Pan American, USA

Hesri Faizal Mohamed Din, Universiti Teknologi MARA, Malaysia

Normah H. Omar, Ph.D., Universiti Teknologi MARA, Malaysia

\begin{abstract}
In identifying relevant red flags to be used to detect possible fraud in financial statements, this study adopts the International Auditing Standard AI240 and adapts the US-based Statement of Auditing Standard No 99 (SAS 99). Both SAS 99 and AI240 classify the red flags into three categories: Opportunity, Pressure, and Rationalization. Opportunity Red Flags are found in situations that are ideal for people to commit fraud more easily due to ineffective internal controls, inadequate supervision or managers overriding internal controls. Pressure Red Flags are circumstances in which people have a financial incentive to commit fraud such as falsely overstating sales or profits to receive their bonuses or exerting pressure on managers to reduce actual expenses to be under budgeted costs. Rationalization Red Flags are situations where people have certain traits and abilities to commit fraud and justify it with false reasons which they believe are true. A Red Flag Questionnaire which contains 15 demographic multiple choice questions, followed by a five-point Likert scale with questions for 14 Opportunity Red Flags, 15 Pressure Red Flags and 11 Rationalization Red Flags was developed and distributed to three groups of auditors: External, internal and governmental. The study indicates the direct or inverse relationships between each demographic factor and each red flag. These relationships were identified by using multiple regression models. Three types of relationships are possible: direct, inverse and no relationship. These three types of relationships are as follows: (1) the relationship between the level of fraud-detecting effectiveness of each Opportunity Red Flag and each demographic factor, (2) the relationship between the level of fraud-detecting effectiveness of each Pressure Red Flag and each demographic factor, and (3) the relationship between the level of fraud-detecting effectiveness of each Rationalization Red Flag and each demographic factor. These relationships indicate which specific professional demographic factors are more likely associated with more effective fraud-detecting red flags. In contrast, other relationships also indicate which specific demographic factors are more likely associated with less effective fraud-detecting red flags. In conclusion, this research project should be conducted in other countries, so the result from one country can be compared to the results from other countries. Some results may vary between developed countries and developing countries. The learning curve or the period of time necessary for auditors to learn how to use red flags and then interpret the findings may also explain differences in the results between countries. This study may enhance the auditors' understanding of the different levels of fraud-detecting effectiveness of red flags as well as when the auditors may benefit from using them in financial statement audits.
\end{abstract}

\section{INTRODUCTION}

7hilst the auditing standards used in the United States may differ "in form" to those standards that are applicable in Malaysia, there are a lot of "in spirit" similarities between them (the standards). The United States practices the so-called rules-based auditing standards where specific details are prescribed in an attempt to address as many potential contingencies as possible. Malaysia on the other hand adopts the International Financial Reporting Standards (IFRS) where standards are basically principles-based. Auditors therefore can use their professional judgments in developing and applying the standards. Basic concepts and their interpretations are nevertheless detailed out in the later standards. 
In the context of detecting fraudulent financial reporting activities in financial statement audits, US auditors are governed by the Statement on Auditing Standard 99 (SAS 99). Specifically, this standard requires auditors to include a significantly increased emphasis and efforts on identifying financial statement fraud during their audit. This would include scrutinizing journal entries, adjustments, accounting estimates and unusual transactions and to look for material misstatement due to fraud. As such, the standard requires auditors to identify and assess fraud risks and how auditors should responds to such risks. The standard includes an expanded fraud risk model which considers (i) incentives/pressures, (ii) opportunities and (iii) rationalization related to fraud.

With respect the auditors' responsibility to consider fraud in an audit of financial statement; Malaysian auditors are governed by the principle-based, International Standard on Auditing 240 (ISA/AI240). ISA 240 provides to a certain extent, some form of "leeways" for an auditor to exercise his or her professional judgment in determining whether a fraud risk factor is present and whether it is to be considered in assessing the risks of material misstatement of the financial statement due to fraud. As in the case of SAS 99, ISA 240 too classifies fraud risk factors into the fraud triangle dimensions namely incentive, opportunity and rationalization.

Since there are more similarities (than differences) between the two standards, it is possible for the SAS 99's fraud risk factors to be adapted and compared with the Malaysian fraud risks questionnaire in this study. For the purpose of this study, the forty two fraud risk red flags as depicted by SAS 99 and used in the studies by Moyes were found to be relevant and suitable for the Malaysian study. Besides making it possible to compare both US and Malaysian studies, SAS 99 provides specific details on elements represented by the fraud triangle theory.

This study explores five research questions. First, do the red flags have the same or different levels of effectiveness in detecting fraud? Second, do the three types of auditors perceive each red flag to have the same or different levels of fraud-detecting effectiveness? Third, do the demographic factors predict in any way the red flags which are more effective in detecting fraud? Fourth, do the demographic factors determine which type of auditor is more likely to detect fraud more effectively than other types of auditors? Fifth, is the relationship between each red flag and each demographic factor direct or inverse?

Both AI240 and SAS 99 classify the red flags into three categories: Opportunity, Pressure, and Rationalization. Opportunity Red Flags are situations that are ideal for people to commit fraud more easily due to ineffective internal controls, inadequate supervision or managers overriding internal controls. Pressure Red Flags are circumstances where people have a financial incentive to commit fraud such as falsely overstating sales or profits to receive their bonuses or exerting pressure on managers to reduce actual expenses to be under budgeted costs. Rationalization Red Flags are situations where people have certain traits and abilities to commit fraud and justify it with false reasons which they believe are true. An example is an employee who embezzles cash from his employer and justifies the fraud by the fact that the employee is underpaid. In this study, the Red Flag Questionnaire designed by Hesri Faizal Mohamed Din used a five-point Likert scale, by which the auditors would indicate their perceptions of how effective each red flag was in detecting fraud. As a result, the Red Flag Questionnaire contained 15 demographic multiple choice questions followed by five-point Likert scale questions for 29 Opportunity Red Flags, 15 Pressure Red Flags, and 15 Rationalization Red Flags.

\section{PRIOR STUDIES}

This Malaysian article is very similar to a large study conducted in the United States where the principal researcher was Glen D. Moyes. From the American study, six articles have been written and published in journals, of which one journal was a reprint at the request of the journal editor. The results and conclusions from the six prior studies can be generally summarized by the following two statements: First, the level of fraud-detecting effectiveness of the 42 SAS No. 99 red flags can be classified by statistical testing into three categories: more effective, average effectiveness, and less effective, as perceived by external auditors, internal auditors, and both external and internal auditors combined (Moyes, et al., 2005; Moyes et al., 2006; Moyes et al., 2007; Moyes, 2008). Second, numerous significant differences exist between external and internal auditors concerning the level of frauddetecting effectiveness of each of the 42 SAS No. 99 red flags that are required to be used in financial statement audits to detect fraudulent financial reporting activities (Lin, P., 2006; Moyes, 2007). Each article provided unique and specific results and conclusions that differentiate it from the other articles. 
In the Malaysian context, published empirical studies on fraud risk red flags have been fairly limited. Since the introduction of AI240 in 2004 and approved in 2005, only four published articles could be detected. The first paper written by Jayalakshmy et al (2005) discusses the changing role of the Malaysian auditors as a result of the increasing corporate and financial frauds globally. External auditors could no longer be content or confined to giving audit opinions. The study calls for "more stringent conditions on fraud detection" to be imposed on auditors. Despite such calls, the paper nevertheless lacks statistical data to support the views of the authors.

Smith et al (2005) conducted a study on a selected sample of Malaysian external auditors. The study basically explores the perception of auditors on the existence and usage of fraud risk factors when they audit the financial statements of their clients. Since the concepts of fraud risk factors were newly introduced then, the variables used to measure financial fraud red flags in this article were also very basic. The study found that though fraud risk factors were perceived to be important, their usage (to detect fraud) by these auditors were somewhat limited. There was also no comparison being made to other similar standards as being practiced by other countries. There was also no reference being made to the three fraud triangle dimensions on that study.

In 2006, a conceptual article was published by Jaafar et. al. on Malaysian auditors The paper basically proposed to develop a conceptual framework linking the external auditors' personality with their ability to detect fraud. Though the paper did discuss the concepts of "fraud and error" as stipulated by AI240, no specific fraud risk red flag was used on their framework. The focus on that study was more on the personality of the external auditors.

Further to their earlier conceptual framework in 2006, Jaafar et al (2007) published another paper highlighting on the use of the "Lens Model" to assess fraud risk by Malaysian Auditors. Despite the lengthy discussion (in the AI240 Appendix) on examples of fraud risk indicators in the standard (AI240), their paper did not use any of the red flags suggested by the said standard. As in their first paper in 2006, the 2007 article was still conceptual in nature.

Premised on the review of these studies, it is evidenced that there remains a large gap in effectively using the fraud risk red flags as suggested by AI240 and further enhanced by the SAS 99. The current study therefore hopes to determine the effective usage of these red flags by Malaysian auditors. Further, in addition to the external auditors, the current study also expanded its sample to include two other categories of auditors namely internal and government auditors. The use of the Fraud Triangle Theory in the analysis of our research findings further enhances our contribution to the body of knowledge.

\section{METHODOLOGY}

\section{Questionnaire Design}

In this study, the Red Flag Questionnaire, designed by Hesri Faizal Mohamed Din (2008), used a five-point Likert scale by which the auditors would indicate their perceptions of how effective each red flag was in detecting fraud. As a result, the Red Flag Questionnaire contained 15 demographic multiple choice questions followed by five-point Likert scale questions for 29 Opportunity Red Flags, 15 Pressure Red Flags, and 15 Rationalization Red Flags.

The research involved mailing 200 red flag questionnaires to 200 external auditors, 200 internal auditors, and 200 government auditors. The mailing list of names and addresses for the external auditors was acquired from the Malaysian Institute of Accountants, the mailing list for the internal auditors was acquired from the Malaysian Institute of Internal Auditors, and the mailing list for the governmental auditors was acquired from the Auditor General Office located in Putrajaya, Malaysia. A total of 135 completed questionnaires were respectively received from: 40 external auditors, 52 internal auditors, and 43 governmental auditors. The response rate was 20 percent for external auditors, 26 percent for internal auditors, 22 percent for governmental auditors, and 23 percent for all three types of auditors combined. All four response rates exceeded 20 percent and are considered a moderate number of completed questionnaires returned to the researcher. 


\section{Data Collection and Analysis}

The average of the responses from each group of auditors represents the level of effectiveness of one particular red flag in detecting fraud. For example, a higher average indicates that the red flag is more effective in detecting fraud. Most of the averages in Tables 2, 3 and 4 are very close to the value of "4," which indicates the auditor responses are skewed to the higher values on the five-point Likert scale, possibly due to the Asian (five percent of Malaysian population is Asian) tendency to respond near the midpoint on the Likert scale (Lee et al., 2002; Spector, 1992; Heine et al., 2002; Denison et al., 2004; Chen et al., 2006), a longer learning curve to understand red flags for Malaysian auditors, and the cross-cultural differences between Malaysia and the United States. The five-point Likert scale used on the red flag questionnaire ranged from the value of "1" indicating extremely not effective in detecting fraud using red flags to the value of " 5 " indicating it is extremely effective in detecting fraud using red flags. The midpoint of this five-point Likert is the value of " 3 " indicating no effectiveness in detecting fraud using red flags.

In most of the multiple regression models, the adjusted $\mathrm{R}$ square values are moderately high, in that the adjusted R-square values range between .2 and .3. Considering that 135 red flag questionnaires were completed and returned to the principal researcher, the data analysis discovered 102 relationships between the professional demographic factors and the level of fraud-detecting effectiveness of the red flags according to external, internal and governmental auditors out of a maximum 2,655 such relationships possible in this Malaysian study.

\section{Demographic Information about External, Internal and Governmental Auditors}

Table 1 shows the differences and similarities in demographic factors among External, Internal and Government Auditors. In Table 1, the number of responses from external, internal and governmental auditors is reported as answers to each of the 15 professional demographic factors. The Chi-Square and One-Way Analysis of Variances with the Scheffe tests were conducted on the 15 following professional demographic factors in Table 1 in order to determine significance.

In analyzing gender in Table 1, more men are internal auditors than women, and more women are governmental auditors than men. In the external auditing profession, the number of men and women are equal. Men seem to prefer the internal auditing profession more than women, and women seem to prefer the governmental auditing profession more than men. Both men and women may prefer external auditing profession equally. These differences between gender and the three types of auditors are significant $(\mathrm{p}=.004)$ according to the Chi-Square test.

In reference to the years of auditing experience in Table 1, 44 internal auditors and 40 governmental auditors have more than three years of experience, whereas 34 external auditors have less than six years of auditing experience. In general, the internal and governmental auditors have more auditing experience than external auditors. The differences between years of auditing experience and the three types of auditors are significant $(\mathrm{p}=.0005)$ according the Chi-Square test. The high turnover of CPAs or external auditors in CPA firms explains the fact they have less years of experience than internal and governmental auditors.

In reviewing educational level and the number of accounting certifications, most external, internal and governmental auditors graduated with a bachelor's degree. Governmental auditors have more graduate degrees than internal auditors, and internal auditors have more graduate degrees than the external auditors. In addition, the external and internal auditors have more accounting certifications than the governmental auditors. The differences between educational level/number of accounting certifications are significant $(\mathrm{p}=.003)$ according to the Chi-Square test.

In analyzing job positions or job titles of auditors in Table 1, 27 external auditors are Associates, and 14 external auditors are Partners, Executive Directors, Senior Managers, and Executive Seniors. In comparison, 20 internal auditors are Senior Executives and Executives, and 31 external auditors are Assistant Managers and Managers. The differences between job positions/job titles are significant ( $\mathrm{p}=.0005)$ according to the Chi-Square test. Apparently, a higher percentage of the internal auditors are in various levels of management when compared to the external auditors due to the employee turnover with CPA firms. 
Table 1

Demographic Information About External, Internal and Governmental Auditors

\begin{tabular}{|c|c|c|c|c|}
\hline \multirow[b]{2}{*}{ Demographic Information } & \multirow[b]{2}{*}{ Types of Auditor Responses } & \multicolumn{3}{|c|}{ Number of Auditors } \\
\hline & & $\begin{array}{l}\text { External } \\
\text { Auditors }\end{array}$ & $\begin{array}{l}\text { Internal } \\
\text { Auditors }\end{array}$ & $\begin{array}{c}\text { Government } \\
\text { Auditors } \\
\end{array}$ \\
\hline 1. Gender & $\begin{array}{l}\text { Males } \\
\text { Females }\end{array}$ & $\begin{array}{l}20 * \\
20 *\end{array}$ & $\begin{array}{l}36^{*} \\
16^{*}\end{array}$ & $\begin{array}{l}15^{*} \\
28 *\end{array}$ \\
\hline 2. Type of Auditors & $\begin{array}{l}\text { External } \\
\text { Internal } \\
\text { Government }\end{array}$ & $\begin{array}{c}40 \\
0 \\
0\end{array}$ & $\begin{array}{c}0 \\
52 \\
0\end{array}$ & $\begin{array}{c}0 \\
0 \\
43\end{array}$ \\
\hline 3. Years in Audit Experience & $\begin{array}{l}<3 \text { years } \\
3 \text { to } 6 \text { years } \\
7 \text { to } 10 \text { years } \\
>10 \text { years }\end{array}$ & $\begin{array}{c}13 * \\
21 * \\
5 * \\
1 *\end{array}$ & $\begin{array}{l}8^{*} \\
15^{*} \\
16^{*} \\
13^{*}\end{array}$ & $\begin{array}{c}3 * \\
14 * \\
3 * \\
23 *\end{array}$ \\
\hline 4. Highest Educational Qualifications & $\begin{array}{l}\text { Diploma } \\
\text { Bachelor's } \\
\text { Master's/Ph.D. } \\
\text { Certifications } \\
\end{array}$ & $\begin{array}{c}0^{*} \\
30 * \\
2 * \\
8 * \\
\end{array}$ & $\begin{array}{c}5 * \\
29 * \\
8 * \\
10 *\end{array}$ & $\begin{array}{c}* \\
22 * \\
12 * \\
2 * \\
\end{array}$ \\
\hline $\begin{array}{l}\text { 5. External Auditor Position/Job Title } \\
\text { (Current) }\end{array}$ & $\begin{array}{l}\text { Partner } \\
\text { Executive Director } \\
\text { Senior Manager } \\
\text { Executive Senior } \\
\text { Associate }\end{array}$ & $\begin{array}{c}2 * \\
1 * \\
5 * \\
5 * \\
27 * \\
\end{array}$ & $\begin{array}{l}0 \\
0 \\
0 \\
0 \\
0 \\
\end{array}$ & $\begin{array}{l}0 \\
0 \\
0 \\
0 \\
0 \\
\end{array}$ \\
\hline $\begin{array}{l}\text { 6. Internal Auditor Position/Job Title } \\
\text { (Current) }\end{array}$ & $\begin{array}{l}\text { General Manager } \\
\text { Manager } \\
\text { Assistant Manager } \\
\text { Senior Executive } \\
\text { Executive }\end{array}$ & $\begin{array}{l}0 \\
0 \\
0 \\
0 \\
0\end{array}$ & $\begin{array}{c}1^{*} \\
18^{*} \\
13 * \\
11^{*} \\
9 *\end{array}$ & $\begin{array}{l}0 \\
0 \\
0 \\
0 \\
0\end{array}$ \\
\hline $\begin{array}{l}\text { 7. Government Auditor Position/Job } \\
\text { Title (Current) }\end{array}$ & Auditor & 0 & 0 & $43^{*}$ \\
\hline $\begin{array}{l}\text { 8. Number of Fraud Detection-related } \\
\text { courses Auditors attended in the last } \\
3 \text { years }\end{array}$ & $\begin{array}{l}\text { Never } \\
\text { Sometimes(1-3times) } \\
\text { Often (4-5 times) } \\
\text { Always }\end{array}$ & $\begin{array}{c}3 * \\
23 * \\
13 * \\
1 *\end{array}$ & $\begin{array}{c}14 * \\
35^{*} \\
3 * \\
0\end{array}$ & $\begin{array}{c}12 * \\
27 * \\
4 * \\
0\end{array}$ \\
\hline $\begin{array}{l}\text { 9. Organizers/Sponsors of Fraud } \\
\text { Detection-related courses that } \\
\text { Auditors have attended }\end{array}$ & $\begin{array}{l}\text { In-House Training } \\
\text { Malaysian Institute-Accountants } \\
\text { Accounting Professional Bodies } \\
\text { Association-Cert Fraud Examiner } \\
\text { Others }\end{array}$ & $\begin{array}{c}26 * \\
12 * \\
1 * \\
0 \\
1 *\end{array}$ & $\begin{array}{l}14 * \\
2 * \\
7 * \\
2 * \\
27 *\end{array}$ & $\begin{array}{c}21 * \\
1 * \\
3 * \\
0 \\
18 *\end{array}$ \\
\hline $\begin{array}{l}\text { 10. Auditors' ability to Detect Fraud } \\
\text { using Red Flags }\end{array}$ & $\begin{array}{l}\text { Not at All } \\
\text { To Some Extent } \\
\text { To a Great Extent }\end{array}$ & $\begin{array}{c}2 \\
29 \\
9\end{array}$ & $\begin{array}{c}3 \\
43 \\
6\end{array}$ & $\begin{array}{c}0 \\
39 \\
4 \\
\end{array}$ \\
\hline $\begin{array}{l}\text { 11. Employers assume Auditors are } \\
\text { Fully Responsible for Fraud } \\
\text { Detection }\end{array}$ & $\begin{array}{l}\text { Not at All } \\
\text { To Some Extent } \\
\text { To a Great Extent }\end{array}$ & $\begin{array}{c}7 * \\
32 * \\
1 *\end{array}$ & $\begin{array}{l}23^{*} \\
25^{*} \\
4 *\end{array}$ & $\begin{array}{c}8 * \\
29 * \\
6 *\end{array}$ \\
\hline $\begin{array}{l}\text { 12. Availability of Current Legal } \\
\text { Framework is Sufficient to reduce } \\
\text { Financial Fraud }\end{array}$ & $\begin{array}{l}\text { Not at All } \\
\text { To Some Extent } \\
\text { To a Great Extent }\end{array}$ & $\begin{array}{c}5 \\
35 \\
0 \\
\end{array}$ & $\begin{array}{c}5 \\
44 \\
3 \\
\end{array}$ & $\begin{array}{c}7 \\
33 \\
3 \\
\end{array}$ \\
\hline $\begin{array}{l}\text { 13. Enforcement of current legal } \\
\text { framework is Sufficient to curb } \\
\text { Financial Fraud }\end{array}$ & $\begin{array}{l}\text { Not at All } \\
\text { To Some Extent } \\
\text { To a Great Extent }\end{array}$ & $\begin{array}{c}9 \\
31 \\
0\end{array}$ & $\begin{array}{c}8 \\
43 \\
1\end{array}$ & $\begin{array}{c}6 \\
35 \\
2 \\
\end{array}$ \\
\hline $\begin{array}{l}\text { 14. Companies Maintain Sufficient } \\
\text { Preventive Measures to reduce } \\
\text { Financial Fraud }\end{array}$ & $\begin{array}{l}\text { Not at All } \\
\text { To Some Extent } \\
\text { To a Great Extent }\end{array}$ & $\begin{array}{c}8 * \\
30 * \\
2 *\end{array}$ & $\begin{array}{l}0 * \\
47 * \\
5 * \\
* * *\end{array}$ & $\begin{array}{c}4 * \\
38 * \\
1 * \\
* * *\end{array}$ \\
\hline $\begin{array}{l}\text { 15. Auditors are Well Trained to } \\
\text { Detect Financial Fraud by Using Red } \\
\text { Flags }\end{array}$ & $\begin{array}{l}\text { Not at All } \\
\text { To Some Extent } \\
\text { To a Great Extent }\end{array}$ & $\begin{array}{l}10 * * * \\
28 * * * \\
2 * * *\end{array}$ & $\begin{array}{c}6 * * * \\
46 * * * \\
0\end{array}$ & $\begin{array}{c}7 * * * \\
36 * * * \\
0\end{array}$ \\
\hline
\end{tabular}


In reference to fraud detection-related courses in Table 1, the majority of internal and governmental auditors attend fraud detection-related courses ranging from never to sometimes. In contrast, the majority of the external auditors attend fraud detection-related courses ranging from sometimes to often. The differences between the number of fraud detection-related courses attended by auditors and the three types of auditors are significant $(\mathrm{p}=.003)$. Evidently, external auditors attend fraud detection-related courses more than both internal and governmental auditors.

In reviewing organizers of fraud detection-related courses in Table 1, most of the organizers of these courses that internal and governmental auditors attend, utilize in-house training by employers and other types of organizers. In comparison, most of the organizers of fraud detection-related courses, which external auditors attend, utilize in-house training by employers and by the Malaysian Institute of Accountants. The differences between the types of organizers of fraud detection-related courses and the three types of auditors are significant $(\mathrm{p}=.005)$ according to the Chi-Square test. The most common organizer of fraud detection-related courses is employers that offer in-house training.

In Table 1, external, internal and governmental auditors considered the level of fraud-detecting effectiveness as being moderate, which are in the middle, between more effective and less effective. All three types of auditors surveyed consider their ability to detect fraud using red flags as moderate, but not extremely low or extremely high.

In Table 1, external and governmental auditors perceive their employers assume that their auditors are responsible for fraud detection using red flags. In comparison, internal auditors perceive their employers assume that their auditors are responsible in a range from not at all to some extent for fraud detection using red flags. The differences between employers assuming their auditors are fully responsible for fraud detection and the three types of auditors are significant $(\mathrm{p}=.005)$ according to the Chi-Square test. All three types of auditors surveyed assume that their employers held them responsible for fraud detection to some extent.

In Table 1, both the availability and enforcement of the current legal framework are sufficient to detect and reduce fraud using red flags to some extent as perceived by external, internal and governmental auditors. Also, employers maintain sufficient preventive measures to detect and reduce fraud using red flags to some extent as perceived by external, internal and governmental auditors. Auditors are well trained to detect fraud using red flags to some extent according to all three types of auditors surveyed.

In analyzing companies maintaining sufficient preventive measures to detect and reduce fraud in Table 1, external, internal and governmental auditors perceive that companies maintain sufficient preventive measures to some extent. The differences between companies maintaining sufficient preventive measures to detect and reduce fraud and the three types of auditors are significant ( $\mathrm{p}=.011)$ according to the Chi-Square test. According to the one-way analysis of variance test and the Scheffe test, a significant difference $(\mathrm{p}<.10)$ exists between internal and governmental auditors concerning the use of sufficient measures by companies to detect and reduce fraud. Internal auditors conduct audits in accordance with professional auditing standards, whereas governmental auditors conduct audits in accordance with applicable laws.

In reviewing whether auditors have been well trained to detect fraud using red flags in Table 1, external, internal and governmental auditors perceive that auditors are well trained to detect fraud using red flags to some extent. According to the Chi-Square test, significant $(\mathrm{p}=.086)$ differences exist between the three types of auditors and sufficient training of auditors to detect fraud in using red flags. 


\section{RESULTS CONCERNING FRAUD-DETECTING EFFECTIVENESS OF RED FLAGS AS PERCEIVED BY EXTERNAL, INTERNAL AND GOVERNMENTAL AUDITORS}

\section{Level of Fraud-Detecting Effectiveness of Opportunity Red Flags}

Table 2 shows the average of the External Auditors' responses for each Opportunity Red Flag, the average of the Internal Auditors' responses for each Opportunity Red Flag and the average of the Government Auditors' responses for each Opportunity Red Flag.

In the Malaysian study, the level of fraud-detecting effectiveness was perceived to be the same for all 40 red flags by external, internal and governmental auditors. In fact, all three types of auditors surveyed in this Malaysian study perceived the level of fraud-detecting effectiveness of the 40 red flags by external, internal and governmental auditors to be the average value of "4" on a five-point Likert scale, which indicates each of the 40 red flags are considered to be generally effective in detecting fraud according to all three types of auditors surveyed.

The averages or means of responses from each of the three types of auditors for each of the 14 Opportunity Red Flags was approximately the value of " 4 " on a five-point Likert scale. Therefore, most of the auditor responses are skewed to the higher values on the Likert scale. In the Malaysian study, all three types of auditors responded slightly above the midpoint of the five-point Likert scale, whereas the American auditors responsed to all six different six values on the six-point Likert scale. Asians represent approximately five percent of the entire Malaysian population. From many prior studies (Lee et al., 2002; Spector, 1992; Heine et al., 2002; Denison et al., 2004; Chen et al., 2006), the Asian culture and values are different from American culture and values. These crosscultural differences may partially explain why Asians respond near the midpoint of the Likert scale. The Chinese and Japanese people tend to experience difficulty in selecting the appropriate response on a Likert scale. Therefore, they tend to respond near the midpoint of the Likert scale.

In addition, the learning curve or the period of time required for auditors to understand and comply with the professional auditing standards is generally very long. The Malaysian auditors use the United States Generally Accepted Accounting Standards and the U.S. professional auditing standards. Statement of Auditing Standard No. 99 , which requires auditors to use 42 red flags in financial statement audits to detect fraudulent financial reporting activities, has been in effect for approximately six years. Auditors normally learn to understand and apply a new standard, like the SAS No. 99, over several years. Thus, Malaysian auditors are using a foreign auditing standard and probably are just approaching the end of their learning curve. For these reasons, the Malaysian auditors may respond near the midpoint of the Likert scale because they may be still learning to understand and use the red flags correctly in audits in order to detect fraud.

Finally, cross-cultural differences may influence the fact that Malaysian auditors seem to learn to understand and apply red flags over a long period of time. The cultural aspects of a country influence the way its people incorporate new information. For example, people in most Arabic countries tend to memorize all new information, whereas people in the United States and European countries tend to only partially memorize new information.

\section{Level of Fraud-Detecting Effectiveness of Pressure Red Flags}

Table 3 shows the average of the External Auditors' responses for each Pressure Red Flag, the average of the Internal Auditors' responses for each Pressure Red Flag, and the average of the Government Auditors' responses for each Pressure Red Flag.

The averages or means of responses from each of the three types of auditors for each of the 15 Pressure Red Flags are approximately the value of "4" on a five-point Likert scale. Therefore, most of the auditor responses are skewed to the higher values on the Likert scale. In the Malaysian study, all the three types of auditors responded slightly above the midpoint of the five-point Likert scale, whereas the American auditors response to all six different six values on the six-point Likert scale. Asians represent approximately five percent of the entire Malaysian population. From many prior studies (Lee et al., 2002; Spector, 1992; Heine et al., 2002; Denison et al., 
2004; Chen et al., 2006), the Asian culture and values are different from the American culture and values. These cross-cultural differences may partially explain why Asians respond near the midpoint of the Likert scale. The Chinese and Japanese people experience difficulty in selecting the appropriate response to a Likert scale. Therefore, they tend to respond near the midpoint of the Likert scale.

Table 2

Level of Fraud-Detecting Effectiveness of Opportunity Red Flags as Perceived by External, Internal and Governmental Auditors

\begin{tabular}{|c|c|c|c|}
\hline \multirow{3}{*}{ Opportunity Red Flags } & \multicolumn{3}{|c|}{$\begin{array}{l}\text { Level Of Effectiveness Of Red Flags } \\
\text { In Detecting Fraud }\end{array}$} \\
\hline & External & Internal & Government \\
\hline & Auditors & Auditors & Auditors \\
\hline $\begin{array}{l}\text { 1. Ineffective board of directors or audit committee oversight over the } \\
\text { financial reporting process and internal control system }\end{array}$ & 4.38 & 4.33 & 4.37 \\
\hline 2. Inadequate monitoring of significant internal controls & 4.30 & 4.73 & 4.70 \\
\hline $\begin{array}{l}\text { 3. Assets, liabilities, revenues, or expenses based on significant estimates that } \\
\text { involve subjective judgments or uncertainties that are difficult to corroborate }\end{array}$ & 4.30 & 4.27 & 4.19 \\
\hline $\begin{array}{l}\text { 4. Significant related-party transactions not in the ordinary course of business } \\
\text { or with related entities that are not audited or audited by } \\
\text { Another firm }\end{array}$ & 4.30 & 4.21 & 4.30 \\
\hline $\begin{array}{l}\text { 5. Domination of management by a single person or small group in a non- } \\
\text { owner-managed business without compensating controls }\end{array}$ & 4.20 & 4.31 & 4.37 \\
\hline 6. High turnover of chief executive officers or board of directors & $4.18 * * *$ & $3.88 * * *$ & $3.74 * * *$ \\
\hline $\begin{array}{l}\text { 7. Overly complex organizational structure involving unusual legal entities or } \\
\text { managerial lines of authority }\end{array}$ & 4.13 & 3.83 & 4.09 \\
\hline $\begin{array}{l}\text { 8. Significant, unusual, or highly complex transactions, especially occurring } \\
\text { close to year end that pose difficult "substance over form" questions }\end{array}$ & 4.13 & 4.04 & 4.26 \\
\hline $\begin{array}{l}\text { 9. Significant bank accounts or subsidiary or branch operations in tax-haven } \\
\text { jurisdictions for which there appears to be no clear business justification }\end{array}$ & 4.08 & 4.00 & 4.30 \\
\hline $\begin{array}{l}\text { 10. Ineffective accounting and information systems, including situations } \\
\text { involving reportable conditions }\end{array}$ & 4.05 & 4.33 & 4.26 \\
\hline $\begin{array}{l}\text { 11. High turnover rates or employment of ineffective accounting, internal } \\
\text { audit, or information technology staff }\end{array}$ & 4.00 & 4.17 & 4.30 \\
\hline $\begin{array}{l}\text { 12. Difficulty in determining the organization or individuals that have } \\
\text { controlling interest in the entity }\end{array}$ & 3.85 & 3.83 & 3.74 \\
\hline $\begin{array}{l}\text { 13. A strong financial presence or ability to dominate a certain industry } \\
\text { sector that allows the entity to dictate terms or conditions to suppliers or } \\
\text { customers that may result in inappropriate or not arm's length transactions }\end{array}$ & 3.83 & 3.88 & 3.91 \\
\hline $\begin{array}{l}\text { 14. Significant operations located or conducted across international borders } \\
\text { in jurisdictions where differing business environments and cultures exist }\end{array}$ & 3.75 & 3.62 & 3.79 \\
\hline
\end{tabular}

In addition, the learning curve or the period of time required for auditors to understand and comply with the professional auditing standards is generally very long. The Malaysian auditors use the United States Generally Accepted Accounting Standards and the U.S. professional auditing standards. Statement of Auditing Standard No. 99 , which requires auditors to use 42 red flags in financial statement audits to detect fraudulent financial reporting activities, has been in effect for approximately six years. Auditors normally learn to understand and apply a new standard, like the SAS No. 99, over several years. Thus, Malaysian auditors are using a foreign auditing standard and probably just approaching the end of the learning curve. For these reasons, the Malaysian auditors may respond near the midpoint of the Likert scale, because they may be still learning to understand and use the red flags correctly in audits in order to detect fraud. 
Table 3

Level of Fraud-Detecting Effectiveness of Pressure Red Flags as Perceived by External, Internal and Governmental Auditors

\begin{tabular}{|c|c|c|c|}
\hline \multirow{3}{*}{ Pressure Red Flags } & \multicolumn{3}{|c|}{$\begin{array}{c}\text { Level Of Effectiveness Of Red Flags In } \\
\text { Detecting Fraud }\end{array}$} \\
\hline & External & Internal & Government \\
\hline & Auditors & Auditors & Auditors \\
\hline 1. Marginal ability to meet exchange listing requirements or debt repayment & $4.30 * * *$ & $3.88 * * *$ & 3.72 \\
\hline $\begin{array}{l}\text { 2. Rapid growth or unusual profitability, especially compared to that of other } \\
\text { companies in the same industry }\end{array}$ & 4.25 & 4.04 & 3.74 \\
\hline $\begin{array}{l}\text { 3. Operating losses causing threat of imminent bankruptcy or foreclosure, or } \\
\text { hostile takeover }\end{array}$ & 4.20 & 4.23 & 4.02 \\
\hline $\begin{array}{l}\text { 4. Management and/or board directors holding significant financial interests } \\
\text { in the entity }\end{array}$ & 4.15 & 4.10 & 4.12 \\
\hline $\begin{array}{l}\text { 5. Significant portions of management's compensation, represented } \\
\text { by bonuses and stock options, being contingent upon achieving aggressive } \\
\text { targets for stock price, operating results, financial position, or cash flow }\end{array}$ & 4.15 & 4.04 & 3.81 \\
\hline $\begin{array}{l}\text { 6. Unrealistic profitability or trend-level expectations of investment } \\
\text { analysts, institutional investors, significant creditors or other external } \\
\text { parties in overly optimistic press releases or annual report messages }\end{array}$ & 4.13 & 4.17 & 3.88 \\
\hline $\begin{array}{l}\text { 7. Perceived or real adverse effects of reporting poor financial results } \\
\text { on significant pending transactions, such as business combinations } \\
\text { or contract awards }\end{array}$ & 4.13 & 4.21 & 3.91 \\
\hline $\begin{array}{l}\text { 8. Unrealistic profitability or trend-level expectation by management in overly } \\
\text { optimistic press releases or annual report messages }\end{array}$ & 4.13 & 4.15 & 4.05 \\
\hline $\begin{array}{l}\text { 9. Recurring negative cash flows from operations or an inability to generate } \\
\text { cash flows while reporting earnings and earnings growth }\end{array}$ & 4.13 & 4.27 & 4.05 \\
\hline $\begin{array}{l}\text { 10. Management and/or board directors have personally guaranteed } \\
\text { significant debts of the firm }\end{array}$ & 4.10 & 3.90 & 3.84 \\
\hline $\begin{array}{l}\text { 11. High degree of competition or market saturation accompanied by } \\
\text { declining margins }\end{array}$ & 4.05 & 3.88 & 3.72 \\
\hline $\begin{array}{l}\text { 12. Significant declines in customer demand and increasing business } \\
\text { Failures in the industry or overall economy }\end{array}$ & 3.98 & 4.08 & 3.84 \\
\hline $\begin{array}{l}\text { 13. Need to obtain additional debt or equity financing of major research and } \\
\text { development or capital expenditures to stay competitive }\end{array}$ & 3.93 & 3.81 & 3.53 \\
\hline $\begin{array}{l}\text { 14. High vulnerability to rapid changes in technology, product obsolescence, } \\
\text { or interest rates }\end{array}$ & 3.83 & 3.83 & 3.98 \\
\hline 15. New accounting, statutory, or regulatory requirements & 3.75 & 3.88 & 3.77 \\
\hline
\end{tabular}

\section{Level of Fraud-Detecting Effectiveness of Rationalization Red Flags}

Table 4 shows the average of the External Auditors' responses for each Rationalization Red Flag, the average of the Internal Auditors' responses for each Rationality Red Flag, and the average of the Government Auditors' responses for each Rationalization Red Flag.

The averages or means of responses from each of the three types of auditors for each of the 11 Rationalization Red Flags are approximately the value of " 4 " on a five-point Likert scale. Therefore, most of the auditor responses are skewed to the higher values on the Likert scale. In the Malaysian study, all the three types of auditors responded slightly above the midpoint of the five-point Likert scale, whereas the Americans auditors responded to all six different values on the six-point Likert scale. Asians represent approximately five percent of the entire Malaysian population. From many prior studies (Lee et al., 2002; Spector, 1992; Heine et al., 2002; Denison et al., 2004; Chen et al., 2006), the Asian culture and values are different from the American culture and values. These cross-cultural differences may partially explain why Asians respond near the midpoint of the Likert scale. The Chinese and Japanese people experience some difficult in selecting the appropriate response to Likert scales. Therefore, they tend to respond near the midpoint of the Likert scale. 
In addition, the learning curve or the period of time required for auditors to understand and comply with the professional auditing standards is generally very long. The Malaysian auditors use the United States Generally Accepted Accounting Standards and the U.S. professional auditing standards. Statement of Auditing Standard No. 99, which requires auditors to use 42 red flags in financial statement audits to detect fraudulent financial reporting activities, has been in effect for approximately six years. Auditors normally learn to understand and apply a new standard, like the SAS No. 99, over several years. Thus, Malaysian auditors are using a foreign auditing standard and probably just approaching the end of the learning curve. For these reasons, the Malaysian auditors may respond near the midpoint of the Likert scale, because they may be still learning to understand and use the red flags correctly in audits in order to detect fraud.

Table 4

Level of Fraud-Detecting Effectiveness of Rationalization Red Flags as Perceived by External, Internal and Governmental Auditors

\begin{tabular}{|c|c|c|c|}
\hline \multirow{3}{*}{ Rationalization Red Flags } & \multicolumn{3}{|c|}{$\begin{array}{c}\text { Level Of Effectiveness Of Red Flags } \\
\text { In Detecting Fraud }\end{array}$} \\
\hline & External & Internal & Government \\
\hline & Auditors & Auditors & Auditors \\
\hline $\begin{array}{l}\text { 1. Known history of violations of securities law, or claims against the } \\
\text { entity, its senior management, or board directors alleging fraud or violations of } \\
\text { securities laws }\end{array}$ & 4.10 & 4.23 & 4.30 \\
\hline $\begin{array}{l}\text { 2. Domineering management behavior in dealing with the auditor, especially } \\
\text { involving attempts to influence the scope of the auditor's work }\end{array}$ & 4.08 & 4.21 & 4.35 \\
\hline $\begin{array}{l}\text { 3. An interest by management in employing inappropriate means to } \\
\text { minimize reported earnings for tax-motivated reasons }\end{array}$ & 3.98 & 3.79 & 3.67 \\
\hline $\begin{array}{l}\text { 4. Frequent disputes with the current or previous auditor on accounting, } \\
\text { auditing, or reporting matters }\end{array}$ & 3.95 & 4.00 & 4.30 \\
\hline $\begin{array}{l}\text { 5. Management failure to correct known reportable conditions in internal } \\
\text { controls in a timely basis }\end{array}$ & 3.95 & 4.17 & 4.21 \\
\hline $\begin{array}{l}\text { 6. Excessive interest by management in maintaining or increasing the entity's } \\
\text { stock price or earnings trend }\end{array}$ & 3.90 & 3.85 & 3.77 \\
\hline $\begin{array}{l}\text { 7. Non-financial management's excessive participation in the selection } \\
\text { of accounting principles or the determination of significant estimates }\end{array}$ & 3.85 & 3.81 & 3.77 \\
\hline $\begin{array}{l}\text { 8. Unreasonable demands on the auditor, such as unreasonable time } \\
\text { constraints regarding the completion of the audit or the issuance } \\
\text { of the auditor's report }\end{array}$ & 3.85 & 3.98 & 3.72 \\
\hline $\begin{array}{l}\text { 9. A practice used by management of committing analysts, creditors, and other } \\
\text { third parties to achieve aggressive or unrealistic forecasts }\end{array}$ & 3.85 & 3.79 & 3.65 \\
\hline $\begin{array}{l}\text { 10. Formal or informal restrictions on the auditor that inappropriately } \\
\text { limit his access to people or information or limit his ability to communicate } \\
\text { effectively with the board of directors or the audit committee }\end{array}$ & 3.80 & 4.12 & 3.95 \\
\hline $\begin{array}{l}\text { 11. Recurring attempts by management to justify marginal or inappropriate } \\
\text { accounting on the basis of materiality }\end{array}$ & 3.80 & 4.13 & 4.05 \\
\hline
\end{tabular}

\section{RESULTS CONCERNING RELATIONSHIPS BETWEEN RED FLAGS AND DEMOGRAPHIC FACTORS}

The authors investigated relationships between the demographic factors and the level of fraud-detecting effectiveness of each of the 42 SAS No. 99 red flags by conducting 52 multiple regression equations. In these multiple regression models, the professional demographic factors represented the dependent variables, and the level of effectiveness of each red flag in detecting fraudulent financial reporting activities as perceived by the external, internal and governmental auditors represented the independent variables. In these regression models, the independent variables may or may not predict dependent variables. In other words, the degree of fraud-detecting effectiveness of each red flag may or may not predict specific demographic factors that pertain to auditors who may use the red flags more effectively in detecting detect fraud. According the perceptions of external, internal and governmental auditors, red flags considered as being more effective in fraud detection are more likely to predict 
which specific professional demographic factors are associated with those same auditors, who perceived those same red flags as having more fraud-detecting effectiveness.

Due to the high volume of data analysis, only the significant regression models and significant independent variables will be discussed in this paper. For each significant regression model, the red flags perceived as more effective in fraud detection as the significant independent variables will predict the specific professional demographic factors that belong to the auditors that perceived those same red flags as having more fraud-detecting effectiveness. The not significant regression models and not significant independent variables will be excluded from discussion in this paper. For the reason, the tables, which would show the statistical information about the dependent and independent variables, would be too long in length to be included in this article. Instead, only the critical information about the significant regression models and their significant independent variables will be shown within parentheses. In addition, only standardized beta coefficients rather than the unstandardized beta coefficients for significant independent variables will be included within parentheses. The readers can assume the standardized beta coefficients are all positive, unless otherwise indicated. Explanations will sometimes be provided for negative coefficients and positive coefficients. Most results are easy for readers to understand.

In this section of the article, extensive data analysis investigated a total of 1,800 possible different relationships between each red flag and each professional demographic factor. This number was calculated by multiplying 40 red flags times 15 demographic factors times 3 auditor groups. There were 600 possible different relationships between red flags and demographic factors for each of the three auditor groups. Due to the high number of statistical relationships, only significant relationships will be shown in the following discussion of results. A total of 180 multiple regression models were run on the SPSS computer program, of which 102 significant independent variables were identified.

In this section of the article, the 40 red flags are categorized: first, by the three SAS No. 99 red flag groups of opportunity, pressure and rationalization and second, by the order of the 15 professional demographic factors.

15 Specific Professional Demographic Factors Relationships with the Level of Fraud-Detecting Effectiveness of the Opportunity Red Flags Numbered 1 through 14 as Perceived by External, Internal and Governmental Auditors

For the external, internal, and governmental auditors, the only significant relationships between the level of fraud-detecting effectiveness of the 15 Opportunity Red Flags (numbered 1 through 14) and the 15 professional demographic factors were marginally significant between five percent and ten percent. Therefore, these relationships will not be discussed.

15 Specific Professional Demographic Factors Relationships with the Level of Fraud-Detecting Effectiveness of the Pressure Red Flags Numbered 1 through 15 as Perceived by External, Internal and Governmental Auditors

For the external, internal, and governmental auditors, the only significant relationships between the level of fraud-detecting effectiveness of the 15 Pressure Red Flags (numbered 1 through 15) and the 15 professional demographic factors were marginally significant between five percent and ten percent. Therefore, these relationships will not be discussed.

15 Specific Professional Demographic Factors Relationships with the Level of Fraud-Detecting Effectiveness of the Rationalization Red Flags Numbered 1 through 11 as Perceived by External, Internal and Governmental Auditors

The following paragraphs will present the significant relationships between the 15 professional demographic factors and the level of fraud-detecting effectiveness of 15 Rationalization Red Flags (numbered 1 through 11) as perceived by external, internal and governmental auditors. 


\section{External Auditors}

For the external auditors, significant relationships exist between five Rationalization Red Flags and two professional demographic factors that will be explained in the following paragraphs.

Fraud Detection-Related Courses Attended by External Auditors. External auditors who have attended fraud detection-related courses, may perceive the following Rationalization Red Flag to be more effective in detecting fraud than external auditors, who have not attended fraud detection-related courses (Regression Model: Significance $=.010$ and Adjusted R Square $=.418$ ).

1. An interest by management in employing inappropriate means to minimize reported earnings for taxmotivated reasons $($ Coefficient $=.747$ and Significance $=.014)$.

Management decisions, which are based solely on tax criteria, tend to minimize taxable income, but such manipulations may cause fraudulent activities.

The two following Rationalization Red Flags have negative coefficients (Regression Model: Significance = .010 and Adjusted R Square = .418). External auditors, who attend the fraud detection-related courses may perceive reportable conditions in ineffective accounting and information systems as less effective in detecting fraud than external auditors, who do not attend such courses.

1. Frequent disputes with the current or predecessor auditor on accounting, auditing, or reporting matters (Coefficient $=-.566$ and Significance $=.037$ ).

2. A practice used by management of committing to analysts, creditors, and other third parties to achieve aggressive or unrealistic forecasts (Coefficient $=-.922$ and Significance $=.002$ ).

Disputes between external auditors and corporate audit clients may involve management's preferences to select accounting standards, that are not generally accepted accounting principles or to conduct some illegal acts against the professional advice of the external auditors. In addition, those managers who guarantee unrealistic earnings estimates to analysts are more likely to commit fraudulent activities to achieve actual higher earnings. It is surprising that these red flags are not considered more effective by the external auditors surveyed.

Company Maintaining Sufficient Preventive Measures to Reduce Fraud as Perceived by External Auditors. External auditors perceive the two following Rationalization Red Flags to be more effective in fraud detection, where the company maintains sufficient preventive measures to decrease fraud (Regression Model: Significance $=$ .018 and Adjusted R Square $=.382$ ).

1. Known history of violations of securities law, or claims against the entity, its senior management, or board of directors alleging fraud or violations of securities laws (Coefficient $=.661$ and Significance $=.019$ ).

2. Non-financial management's excessive participation in the selection of accounting principles or the determination of significant estimates $($ Coefficient $=.620$ and Significance $=.002)$.

When managers violate federal securities laws or managers select accounting principles against the advice of their corporate accountants and external auditors, these red flags may more effective in indicating that fraudulent activities are occurring according to external auditors

\section{Internal Auditors}

For the internal auditors, significant relationships exist between one Rationalization Red Flag and one professional demographic factor that will be explained in the following paragraphs.

Organizers and sponsors of Fraud Detection-Related Courses Attended by Internal Auditors. The following Rationalization Red Flag has a negative coefficient. Internal auditors attending more prestigious red flag-related courses or conferences may perceive the following Rationalization Red Flag to be less effective in detecting fraud 
than internal auditors who attend red flag-related courses or conferences offered by less recognized organizers and/or sponsors (Regression Model: Significance $=.012$ and Adjusted R Square $=.305$ ).

1. An interest by management in employing inappropriate means to minimize reported earnings for taxmotivated reasons $($ Coefficient $=-.869$ and Significance $=.002$ ).

Attendance to more prestigious red flag-related conferences may educate the internal auditors to be more skeptical and analytical in using red flags to detect fraud to the point, that some internal auditors may not consider tax motivations to minimize net income as being more indicative of fraudulent activities.

\section{Governmental Auditors}

For the governmental auditors, significant relationships exist between four Rationalization Red Flags and two professional demographic factors that will be explained in the following paragraphs.

Enforcement of Current Legal Framework as Perceived by Governmental Auditors. Governmental auditors who believe in enforcement of the current legal framework, may perceive the following Rationalization Red Flag to be considered more effective in detecting fraud than governmental auditors who do not believe in enforcement of the current legal framework (Regression Model: Significance $=.029$ and Adjusted R Square $=.316$ ).

1. Recurring attempts by management to justify marginal or inappropriate accounting on the basis of materiality $($ Coefficient $=.646$ and Significance $=.009)$.

Materiality decisions are solely based on the professional judgment of governmental auditor. In other words, the dollar amount of an accounting issue may be considered material by one governmental auditor, but not material by another auditor. Governmental auditors who believe more strongly about enforcement of laws are more likely to be more conservatively and consider smaller dollar amounts as being material.

The following Rationalization Red Flag has a negative coefficient (Regression Model: Significance $=.029$ and Adjusted R Square =.316). Governmental auditors, who believe in enforcement of the current legal framework, seem to perceive the following Rationalization Red Flag as being less effective in detecting fraud than governmental auditors who do not believe in enforcement of the current legal framework.

1. Domineering management behavior in dealing with the auditor, especially involving attempts to influence the scope of the auditor's work (Coefficient $=-.588$ and Significance $=.024$ ).

Governmental auditors, who believe in enforcement of laws, are more likely to speculate that managers, who influence the auditors' work, are not committing fraud, until the managers actually violate specific laws.

Company Maintaining Sufficient Preventive Measures to Reduce Fraud as Perceived by Governmental Auditors. Governmental auditors perceive the following Rationalization Red Flag to be more effective in fraud detection when the company maintains sufficient preventive measures to decrease fraud (Regression Model: Significance $=.006$ and Adjusted R Square $=.421$ ).

1. Recurring attempts by management to justify marginal or inappropriate accounting on the basis of materiality $($ Coefficient $=.733$ and Significance $=.002)$.

Managers who repeatedly attempt to justify their accounting decisions based solely on the materiality principle may be less ethical, so that companies maintaining sufficient preventive measures to reduce fraud, may consider investigating these questionable managers.

The following Rationalization Red Flag has a negative coefficient (Regression Model: Significance $=.006$ and Adjusted R Square = .421). The following Rationalization Red Flag seem to be perceived as having less fraud- 
detecting effectiveness, in cases where, the companies, being audited, do not maintain sufficient preventive measures to detect fraud.

1. Known history of violations of securities law, or claims against the entity, its senior management, or board of directors alleging fraud or violations of securities laws (Coefficient $=-.680$ and Significance $=.001)$.

Managers of publicly held corporations, which do not maintain sufficient preventive measures, in general possess less concern about compliance with laws.

\section{CONCLUSIONS}

The conclusions will summarize the results in an outline format. The 40 red flags are categorized first in the order of the three types of auditors and second in the order of the 15 professional demographic factors. The conclusions in this section of the article are in the reverse order of the results section.

\section{Professional Demographic Factors}

More men are internal auditors than women, and more women are governmental auditors than men. Internal and governmental auditors in general have more years of experience than external auditors.

Governmental auditors have more graduate degrees than internal auditors, and internal auditors have more graduate degrees than external auditors. In addition, the external and internal auditors have more accounting certifications than the governmental auditors.

A higher percentage of internal auditors are in various levels of management when compared to external auditors due to the employee turnover with CPA firms. High turnover is a problem that every CPA firm experiences.

External auditors attend fraud detection-related courses more than both internal and governmental auditors. The most common organizer of fraud detection-related courses is employers that offer in-house training. In addition, all three types of auditors surveyed assume that their employers held them responsible for fraud detection using red flags to some extent.

Both the availability and enforcement of the current legal framework are sufficient to detect and reduce fraud using red flags to some extent as perceived by external, internal and governmental auditors. In addition, employers maintain sufficient preventive measures to detect and reduce fraud using red flags to some extent as perceived by all three types of auditors surveyed. Finally, auditors are well trained to detect fraud using red flags to some extent according to all three types of auditors surveyed.

\section{External Auditors}

For external auditors, the red flags are organized in order of the 15 professional demographic factors. The relationship between each red flag and each professional demographic factor is described as direct or inverse. There are significant relationships between specific professional demographic factors and level of fraud-detecting effectiveness of specific red flags, which is almost the same number of relationships for governmental auditors and twice the number of relationships for internal auditors.

\section{Fraud Detection-Related Courses Attended by External Auditors}

Direct Relationship:

1. An interest by management in employing inappropriate means to minimize reported earnings for taxmotivated reasons. 
Inverse Relationship:

1. Frequent disputes with the current or predecessor auditor on accounting, auditing, or reporting matters.

2. A practice used by management of committing to analysts, creditors, and other third parties to achieve aggressive or unrealistic forecasts.

\section{Company Maintaining Sufficient Preventive Measures to Reduce Fraud as Perceived by External Auditors}

Direct Relationship:

1. Known history of violations of securities law, or claims against the entity, its senior management, or board of directors alleging fraud or violations of securities laws.

2. Non-financial management's excessive participation in the selection of accounting principles or the determination of significant estimates.

\section{Internal Auditors}

For the internal auditors, the red flags are organized in order of the 15 professional demographic factors. The relationship between each red flag and each professional demographic factor is described as direct or inverse. There are significant relationships between specific professional demographic factors and level of fraud-detecting effectiveness of specific red flags, which is approximately one-half of the number of relationships for external auditors and for governmental auditors.

\section{Organizers and sponsors of Fraud Detection-Related Courses Attended by Internal Auditors}

Inverse Relationship:

1. An interest by management in employing inappropriate means to minimize reported earnings for taxmotivated reasons.

\section{Governmental Auditors}

For governmental auditors, the red flags are organized in order of the 15 professional demographic factors. The relationship between each red flag and each professional demographic factor is described as direct or inverse. There are significant relationships between specific professional demographic factors and level of fraud-detecting effectiveness of specific red flags, which is almost the same number of relationships for external auditors and onehalf the number of relationships compared to internal auditors.

\section{Enforcement of Current Legal Framework as Perceived by Governmental Auditors}

Direct Relationship:

1. Recurring attempts by management to justify marginal or inappropriate accounting on the basis of materiality.

Inverse Relationship:

1. Domineering management behavior in dealing with the auditor, especially involving attempts to influence the scope of the auditor's work.

Company Maintaining Sufficient Preventive Measures to Reduce Fraud as Perceived by Governmental Auditors

Direct Relationship: 
1. Recurring attempts by management to justify marginal or inappropriate accounting on the basis of materiality.

Inverse Relationship:

1. Known history of violations of securities laws, or claims against the entity, its senior management, or board of directors alleging fraud or violations of securities laws.

\section{Limitations of the Malaysian Study}

In the Mayalsian study, the average of most of the responses from all three types of auditors surveyed is "4" on a five-point Likert scale for each red flag, which implies the auditor responses are skewed to the higher values on the five-point Likert scale for each red flag. There are possible explanations for the Asian response near the midpoint of the Likert scale. First, Asians have a natural tendency to select the midpoint of the Likert scale (Lee et al., 2002; Spector, 1992; Heine et al., 2002; Denison et al., 2004; Chen et al., 2006), because Asians have trouble deciding how to respond to the Likert scale. Secpnd, the Malaysian auditors may have a longer learning curve on understanding and applying red flags than American auditors because the Malaysian auditors use auditing standards from a foreign country, the United States. Third, cross-cultural differences between Malaysia and the United States may affect how people in any country learn new information, such as red flags.

If the number of completed questionnaires received from all three types of auditors were higher, the regression models would probably have been more significant, and the Adjust R Square would probably be slightly higher.

There were more results from the multiple regression models involving Rationalization Red Flags than the results from the multiple regression models involving Pressure and Opportunity Red Flags.

\section{REFERENCES}

1. Chen, C., S. Lee, and H.W. Stevenson. 1995. Response Style and Cross-Cultural Comparisons of Rating Scales Among East Asian and North American Students. Psychological Science (A Journal of the Association of Psychological Sciences). Wiley InterScience (Wiley Periodicals, Inc. and John Wiley and Sons, Inc.), (April 7) 6 (3): 170-175.

2. Denison, D.R., S. Haaland, and P. Goelzer. 2004. Corporate Culture and Organizational Effectiveness: Is Asia Different from the Rest of the World? Organizational Dynamics, Science Direct. (Elsevier, Inc.), 33 (1): 98-109.

3. Din, Hesri Faizal Mohamed. 2008. Survey on the Use of Fraud Risk Red Flags by Auditors Financial Crimology. Master Dissertation. Accounting Research Institute. Universiti Tekmologi MARA.

4. Heine, S.J., D.R. Lehman, J. Greenholtz, K. Peng. 2002. What's Wrong with Cross-Cultural Comparisons of Subjective Likert Scales?: The Reference-Group Effect. Journal of Personality and Social Psychology (American Psychological Association, Inc.), 82 (6): 903-918.

5. Jaffar, N., Salleh, A., Mohd Iskandar, T. and Haron, H. (2007), "The Effect of Fraud Risk Assessment on the External Auditors's Ability to Detect The Likelihood of Fraud: A Conceptual Discussion”, European Journal of Scientific Research, Vol 17, No 3, pp. 425-432.

6. Jaffar, N., Salleh, A., Mohd Iskandar, T. and Haron, H. (2006), “A Conceptual Discussion on the External Auditor's Personality and Detection of Fraud", European Journal of Social Sciences, Vol 4, No 1, pp. 6676.

7. Jayalakshmy, R., Seetharaman, A. and Khong, T. W. (2005), "The Changing Role of Auditors", Managerial Auditing Journal, Vol 20, No 3, pp. 249-271.

8. Lee, J.W., P.S. Jones, Y. Mineyama, and X.E. Zhang. 2002. Cultural Differences in Responses to a Likert Scale. Research in Nursing and Health. Wiley InterScience, (Wiley Periodicals, Inc. and John Wiley and Sons, Inc.), (July 15) 25 (4): 295-306. 
9. Lin, P., Moyes, G.D., Landry, R.M., and Vicdan, H. 2006. Perceived Effectiveness of SAS No. 99 Red Flags: A Comparison Between External and Internal Auditors. Oil, Gas and Energy Quarterly, (December) 55 (2): 337-351.

10. Moyes, G.D., Lin, P., and Landry, R.M. 2005. Raise the Red Flag. Internal Auditor (October) 62 (5): $47-$ 51.

11. Moyes, G.D. 2006. The Differences in Perceived Level of Fraud-Detecting Effectiveness of SAS No. 99 Red Flags Between External and Internal Auditors. Journal of Business and Economics Research, (June) 5 (6): $9-25$.

12. Moyes, G.D., Lin, P., Landry, R.M., and Vicdan, H. 2006. Internal Auditors' Perceptions of the Effectiveness of Red Flags to Detect Fraudulent Financial Reporting Activities. Journal of Accounting, Ethics and Public Policy, 6 (1): 1-16.

13. Moyes, G.D., Lin, P., Landry, R.M., and Vicdan, H. 2007. Internal Auditors' Perceptions of the Effectiveness of Red Flags to Detect Fraudulent Financial Reporting. The Icfai Journal of Audit Practice, (October) 4 (4): 40-57 (Reprinted by Request of the Editor of The Icfai Journal of Audit Practice).

14. Moyes, G.D. 2008. CPAs' Perceptions of Red Flags Used in Detecting Fraud. The Icfai Journal of Audit Practice, (January) 5 (1): 47-60.

15. Smith, M., Omar, N. H., Syad Idris, S.I. Z. and Baharuddin, I (2005), 'Auditors' Perception on Fraud Risk Indicators: Malaysian Evidence”, Managerial Auditing Journal, Vol 20, No 1, pp. 73-85.

16. Spector, P.E. 1992. Summated Rating Scale Construction - An Introduction. Series: Quantitative Applications in the Social Sciences (A Sage University Paper). Sage Publications: Thousand Oaks, California, 82: 1-74. 
NOTES 